\title{
高靶性・高減衰薄板軽量形鋼造耐力壁の開発とその基本力学性能 \\ DEVELOPMENT OF HIGH-DUCTILITY HIGH-DAMPING SHEAR WALL FOR STEEL FRAMED HOUSE AND ITS BASIC MECHANICAL PROPERTIES
}

\author{
曽田 五月也*, 脇 田 健 裕** \\ Satsuya SODA and Takehiro WAKITA
}

\begin{abstract}
We developed a shear wall which exhibits high-ductility and high-damping structural performances when used in steel framed houses. The high ductility can be achieved by fastening plywood with drill screws inside the peripheral steel frames, preventing the plywood from dropping out. The high damping capacity can be achieved by installing the frictional energy-absorbing devices between the stud and inserted plywood panel. We conducted a series of static loading tests and a shaking table test. We also conducted analytical studies on 2-story house models, and confirmed that the wall is quite effective both for reducing the number of walls and suppressing the responses to severe earthquake ground motions.
\end{abstract}

Keywords : Steel framed house, Cold formed steel, Damping property, Shear Wall, F riction D amper スチールハウス, 薄板軽量形鋼造, 減衰, 而力壁, 摩擦ダンパー

\section{1. はじめに}

薄板軽量形鋼造(通称 : スチールハウス)は、板厚 $2.3 \mathrm{~mm}$ 未満の薄 板軽量形鋼に、構造用合板等の面材をドリルねじで留め付けた耐力 パネルを用いて、壁及び床を構成する工法である 1)。20 年ほど前よ り我が国への導入が始まり、現在は主に 2 階建て以下の低層建築物 向けの工法として用いられている。薄板軽量形鋼造による建築物の 耐震性は耐力壁のせん断性能に強く依存し、耐力壁に作用寸るせん 断力は主に面材と枠材のドリル称じ接合部の耐力によって負担され る。現在薄板軽量形鋼造の一般的な耐力壁面材として使用されてい る合板及びせっこうボードのドリルねじ接合部は、耐力壁の変形角 がおよそ $1 / 30[\mathrm{rad}]$ に達すると、ねじの破断及びパンチング(ねじ頭 が面材を貫通寸る破壊)によって急激に耐力を失うため勒性に乏し (2)。また、ドリル称じが面材へめり込むことにより、履歴ループ が強いスリップ性状を示すため、紡錘型の復元力特性を持つ鉄骨ラ 一メン構造等に比べると、薄板軽量形鋼造のエネルギー吸収能力は 低く、変形の繰り返しによる耐力低下も顕著である。

一般的な薄板軽量形鋼造の耐震性に関する研究としては、河合ら

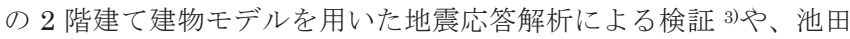
らの $1 \sim 3$ 階建て建物モデルによる地震応答特性に関寸る研究 ${ }^{4)}$ 、菅 野らの振動台実験による検討 5)等が行われており、これらの研究で は進行スリップ形の復元力特性を有するスチールハウス耐力壁は消 費できるエネルギー量に上限があり、極めて稀に発生する地震動に 対しては安全限界変形を超える応答が生じる可能性が有ることが示 されている。

一般的には、薄板軽量形鋼造の耐震性能を向上させるためには、 建物全体の壁数を増やして建物の剛性・強度を増すという方法を用
いるが、この方法では地震時に加速度応答が過大となり、建物内収 容物の移動・転倒・落下等に起因寸る重大な被害が発生する恐れが ある。また、個々の耐力壁のせん断耐力が増大寸ると、耐力壁を支 えるたて枠や金物、基礎への負担も大きくなる。近年、建築基準法 で想定する範囲を超える強い地震動付録 4)が頻発しているが、そのよ うな過酷な地震動に対応するには構造の剛性強度を上げるよりも、 むしろ減衰性能を向上させることが優位と筆者は考えて、高減衰構 造の一般化を目指して来ている。

従来、薄板軽量形鋼造は 3 階建て迄の建築物一の適用に制限され ていたが、2012 年の国土交通省告示 1641 号の改定 ${ }^{6}$ により、4 階 建て迄の建築物への適用が可能となった。薄板軽量形鋼造建築物の 中層化を目指す上では上述の問題点はさらに顕著となるはずである。 そこで本報では、薄板軽量形鋼造耐力壁の勒性とエネルギー吸収 能力を高めることで、建物の剛性及び強度を大幅にアップせずとも、 地震時の変形と加速度の何れをも過大となることを抑制することを 可能とする構造システムを開発し、その基本力学特性を評価した結 果を記す。なお、本論文は日本建築学会大会学術講演 7) 11)において 発表した内容に新たな分析結果を加え，作成したものである。

\section{2. 面材内挿型耐力壁による高勒性化}

\section{1 従来型の薄板軽量形鋼造耐力壁の特徵}

Fig. 1 に国土交通省告示第 1641 号で示される、薄板軽量形構造用 耐力壁の一般的な仕様である構造用合板を面材とする耐力壁の面内 せん断加力試験を行った結果の荷重変形関係 12)の代表的な例を示 す。耐力壁のせん断変形角が $1 / 30[\mathrm{rad}]$ となる加力中に、Photo 1 に 示すように、ドリルねじ接合部のパンチング破壊が発生し急激な耐
* 早稲田大学創造理工学部建築学科 教授. 工博

** 早稲田大学理工学研究所 研究院講師 - 博士 (工学)
Prof., Dept. of Architecture, Waseda University, Dr.Eng.

Assist. Prof., RISE, Waseda University, Dr.Eng. 
力低下に至った。また、耐力壁の履歴性状は衫じ接合部におけるめ り込みにより、強い進行型のスリップ性状を示しており、エネルギ 一吸収能力に乏しいことが分かる。

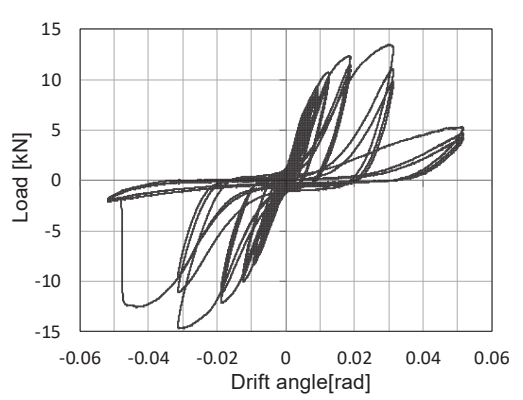

Fig. 1 Load-deflection relation of conventional plywood shear wall11)

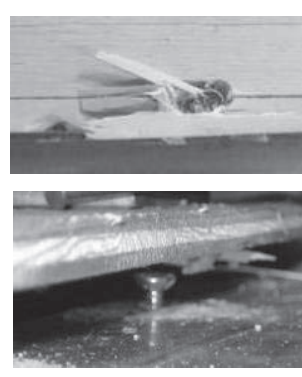

Photo 1 Punching failure of a drill screw joint

\section{2 面材内挿型耐力壁の基本構成}

耐力壁のせん断力に対する勒性を向上させるためには、面材のド リルねじ接合部のめり込みとパンチングを抑制することが有効であ ると考えられる。そこで Fig.2 に示すように、耐力壁面材を補強用 形鋼と共に周辺を構成する枠材の内側に挿入し、形鋼がねじ頭側と なるように面材をドリルねじで留めつけることとした。これにより、 Fig.3 に示すように、耐力壁にせん断力が作用しドリルねじ接合部 に応力が生じる際に、称じ頭側の鋼板が面材に対するめり込みとパ ンチングを抑制すると共に、面材の脱落による急激な強度の低下を 防ぐ仕様とした。また、内挿面材の上下隅角部を切り欠くことで、 耐力壁がせん断力を受け変形する際に、内挿面材の隅角部が水平・ 鉛直枠材の接合部を破壊することを防止する仕様にした。

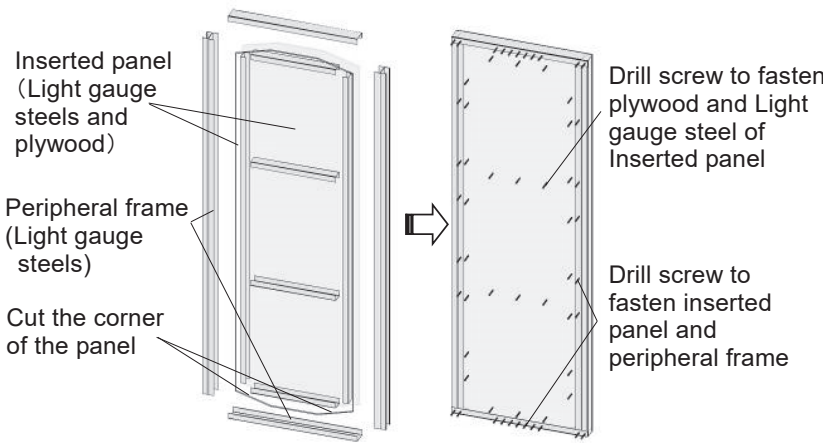

(a)Construction of members

(b)Assemble of members Fig. 2 Image structure of insertion type shear wall

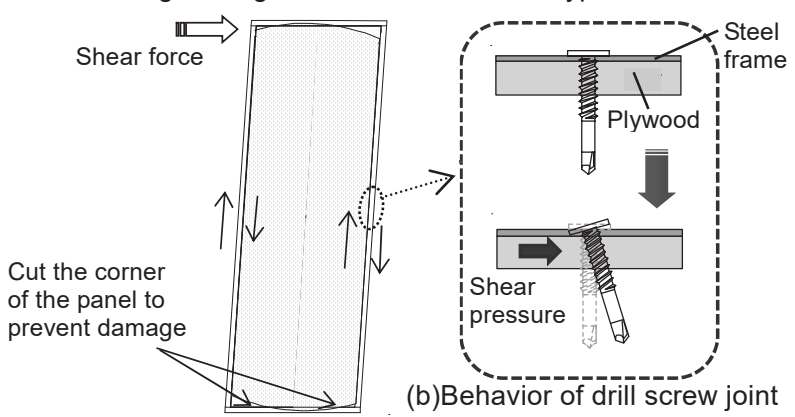

(a)Behavior of wall

Fig.3 Mechanisms of shear wall to resist shear force

\section{3 面材ねじ接合部の単体性能比較}

ねじ頭側を鋼板とした場合の面材ねじ接合部の力学的特性を、そ の単体試験により検討した。試験体は Table 1、Fig5 に示す 2 種類 である。 $\mathrm{P} \rightarrow \mathrm{S}$ と称する試験体は、ねじ頭側に耐力面材が配置され る通常の薄板軽量形構造用耐力壁で用いられる仕様であり、 $\mathrm{S} \rightarrow \mathrm{P}$ と称する試験体が本研究で提案する面材内挿型耐力壁に用いる仕様 である。 $\mathrm{S} \rightarrow \mathrm{P}$ の試験では、Fig.4,Fig5 に示すように、面材の面外方 向への移動を拘束するため、面材両側に配置した形鋼から补じの留 付けを行った。加力は正負交番繰り返しとし、終局に至るまで徐々 に最大変形を大きくしながら加力した。Fig.6 に試験結果を示す。 $\mathrm{P} \rightarrow \mathrm{S}$ では変形が $10 \mathrm{~mm}$ を超えた時点から急激に耐力が低下し、パ ンチングによる急激な破壊を生じたのに対し、 $\mathrm{S} \rightarrow \mathrm{P}$ では最大耐力 值は低いものの、急激な耐力低下はなく高い勒性を有していること が分かる。Photo 2 は $\mathrm{S} \rightarrow \mathrm{P}$ の終局時の状況である。ねじ頭側ではね じの抜け出しがみられるものの、周辺部に大きな損傷は見られない。 ねじ先側では加力方向に沿った面材の支圧破壊が見られた。

Table 1 Specimen for drill screw joint test

\begin{tabular}{|l||l|l|l|l|l|r|}
\hline $\begin{array}{l}\text { Name of } \\
\text { Specimen }\end{array}$ & $\begin{array}{l}\text { Screw head } \\
\text { side material }\end{array}$ & $\begin{array}{l}\text { Screw tip } \\
\text { side material }\end{array}$ & $\begin{array}{l}\text { Thread } \\
\text { diameter }(\phi)\end{array}$ & $\begin{array}{l}\text { Screw head } \\
\text { shape }\end{array}$ & $\begin{array}{l}\text { Number } \\
\text { of screws }\end{array}$ & $\begin{array}{l}\text { Restraint } \\
\text { out of plane }\end{array}$ \\
\hline \hline $\mathrm{P} \rightarrow \mathrm{S}$ & Plywood $(9 \mathrm{~mm})$ & $\begin{array}{r}\text { Light Gauge } \\
\text { Steel }(1.6 \mathrm{~mm})\end{array}$ & $4.2 \mathrm{~mm}$ & Wafer & 2 & 0 \\
\hline $\mathrm{S} \rightarrow \mathrm{P}$ & $\begin{array}{r}\text { Light Gauge } \\
\text { Steel }(1.6 \mathrm{~mm})\end{array}$ & Plywood $(9 \mathrm{~mm})$ & $4.8 \mathrm{~mm}$ & Low Profile & 2 & $\times$ \\
\hline
\end{tabular}

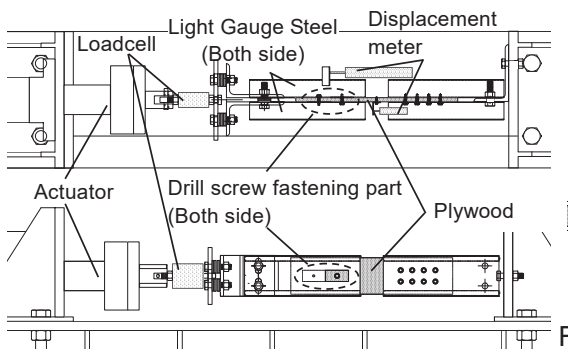

Fig.4 Loading system of drill screw joint test

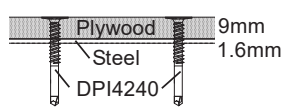
(a) $\mathrm{P} \rightarrow \mathrm{S}$ specimen

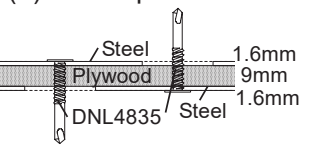

(b) $\mathrm{S} \rightarrow \mathrm{P}$ specimen ig. 5 Detailed drawings of specimens

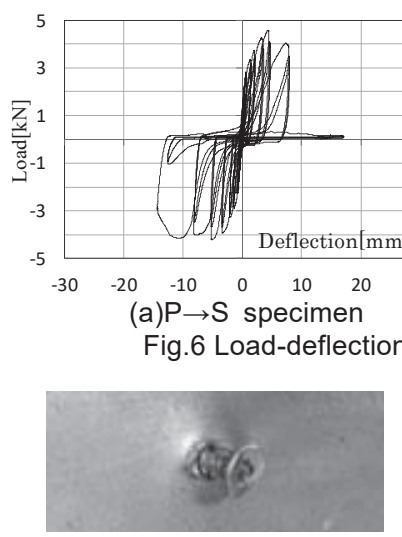

(a)Screw head side

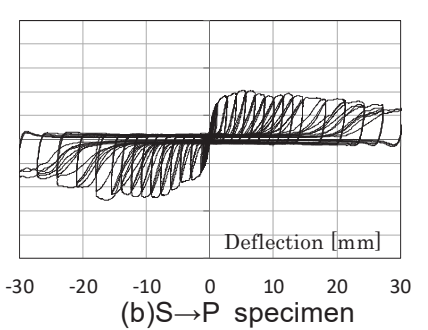

(b) $\mathrm{S} \rightarrow \mathrm{P}$ specime

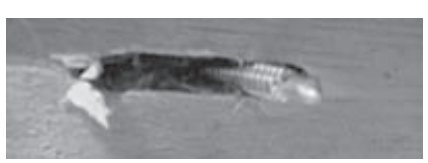

(b)Screw tip side
Photo 2 Failures of a drill screw joint $(S \rightarrow P$ specimen)

\section{4 面材内挿型実大耐力壁の静的加力試験}

面材内挿型耐力壁の力学的特性を実大試験体を用いた静的せん断 加力試験により検討する。Fig.7 に試験体の詳細図を示す。試験体 は幅 $910 \mathrm{~mm}$ 高さ $2730 \mathrm{~mm}$ の $1 \mathrm{P}$ 耐力壁で、内挿パネルの内部に形 鋼を配置し補剛した上で(図中(a))、周辺枠材と内挿パネルをドリル ねじで留め付けて構成した(図中(b))。上下枠材(ランナー)とたて枠 材(スタッド)は各交点をドリルねじ 1 本ずつで接合した。内挿パネ 
ルの面材は上下の切り久き形状を、台形状とした場合と円弧状とし た場合の 2 種類について試験を行い(図中(c))、面材の上下はランナ 一側からドリルねじで片側 7 本ずつ両試験体とも同様に留め付けた。 Fig.8 に試験システム全体図を示す。一般的な薄板軽量形鋼造の 2 階建て戸建住宅を想定し、タイロッドを用いて左右の各縦枠材頭に 均等に $6.5[\mathrm{kN}]$ 、合計 $13[\mathrm{kN}]$ の圧縮力を作用させた状態で加力を行 った。Table2 に本試験に用いた入力波の振幅を示す。載荷方法は正 弦波の漸増振幅正負交番繰り返しとし、变形角 $1 / 450[\mathrm{rad}]$ から $1 / 15[\mathrm{rad}]$ に相当する振幅で各 3 回ずつ繰り返した。
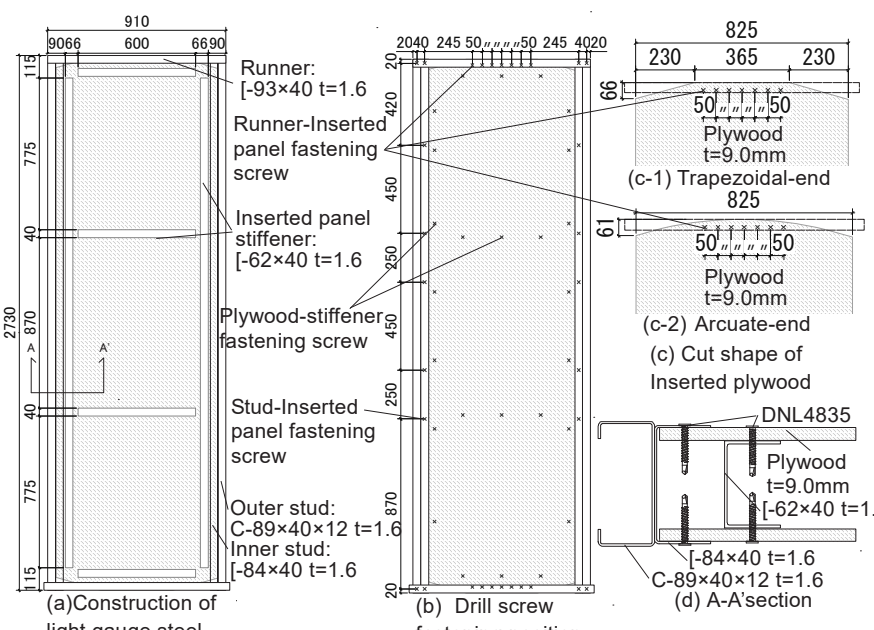
(c-1) Trapezoidal-end

fastening position

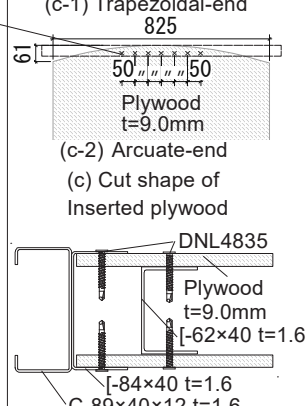

C- $89 \times 40 \times 12 \mathrm{t}=1.6$

Fig.7 Detailed drawings of specimens

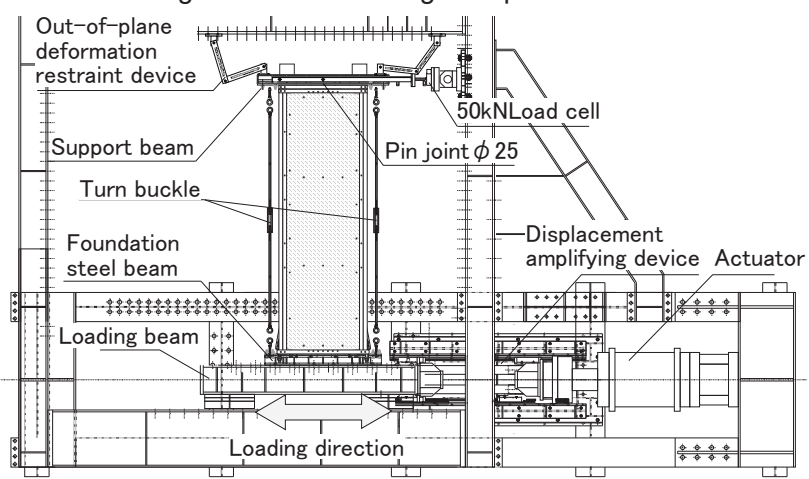

Fig. 8 Loading System

Table 2 Loading schedule

\begin{tabular}{|c|c|c|c|c|c|c|c|c|c|c|}
\hline Drift angle[rad][rad] & $1 / 450$ & $1 / 300$ & $1 / 200$ & $1 / 150$ & $1 / 100$ & $1 / 75$ & $1 / 50$ & $1 / 30$ & $1 / 20$ & $1 / 15$ \\
\hline Displacement $[\mathrm{mm}]$ & 6.1 & 9.1 & 13.7 & 18.2 & 27.3 & 36.4 & 54.6 & 91 & 136.5 & 182 \\
\hline Frequency[Hz] & \multicolumn{10}{|c|}{0.03} \\
\hline
\end{tabular}

Fig.9 に内挿型の 2 種の試験体(面材端部を台形状とした試験体(図 中 Trapezoidal-end/実線)、面材端部を円弧状とした試験体(図中 Arcuate-end/黒の破線) と合板を面材とする一般的な仕様の耐力壁 （以下合板耐力壁、図中 Conventional Plywood/兏色の破線）11)の荷 重変形関係を重礼て示す。なお、実験結果の変形角(図中 Drift angle) は壁の変形角から柱脚の回転角を除いた真の変形角である(以降も 同じ)。合板耐力壁は $1 / 30[\mathrm{rad}]$ 加力時に大きく耐力低下寸るのに対 し、内挿型の試験体は終局変形時まで徐々に低下しながらも最大荷 重の 80\%ほどの耐力を維持し続けている。Table 3 は各試験体の包 絡線から設計用特性值を評価 1) した結果である。塑性率 $\mu$ *が向上し たことにより、構造特性係数 Ds*が小さくなっており、高勒性化の 効果が反映されている。破壊形状は 2.3 の単体試験結果と同様に面
材ねじ接合部のねじ先側面材の支圧破壊であり、切り欠き形状の違 いについては、台形とした方が初期剛性が高く、また端部ドリルね じ接合部の縁端距離の確保によりその損傷も抑制されるため高勒性 化に有利である。

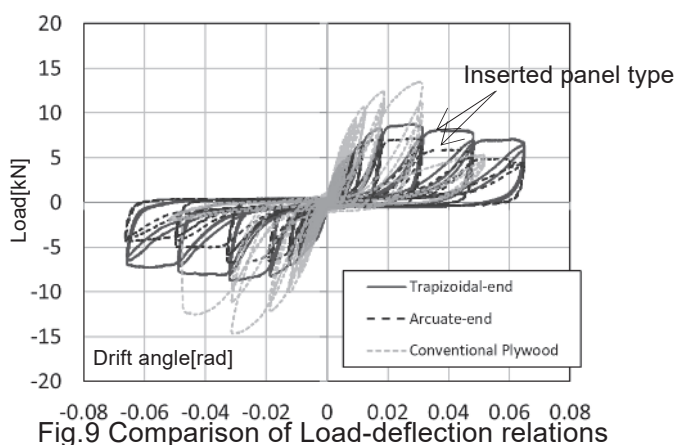

Table 3 Design characteristic values

\begin{tabular}{|c|c|c|c|}
\hline & \multicolumn{2}{|c|}{ Inserted panel type } & \multirow{2}{*}{$\begin{array}{c}\text { Conventional } \\
\text { Plywood }\end{array}$} \\
\hline & Trapezoidal-end & Arcuate-end & \\
\hline Maximum strength Pmax(kN) & 8.73 & 6.96 & 14.07 \\
\hline Yield strength Py(kN) & 4.14 & 3.88 & 8.11 \\
\hline Ultimate strength $\mathrm{Pu}(\mathrm{kN})$ & 7.83 & 6.37 & 12.66 \\
\hline Rigidity K(KN/rad) & 1059 & 987 & 1032 \\
\hline Ductility factor $\mu^{*}$ & 5.10 & 4.28 & 2.37 \\
\hline Ductility Reduction Factor Ds* & 0.33 & 0.36 & 0.52 \\
\hline $\mathrm{Pu} \cdot(0.2 / \mathrm{Ds})(\mathrm{kN})$ & 4.75 & 3.50 & 4.90 \\
\hline $2 / 3 P \max (\mathrm{kN})$ & 5.8 & 4.6 & 9.4 \\
\hline Strength at $1 / 200 \mathrm{rad}(\mathrm{kN})$ & 4.57 & 4.32 & 5.84 \\
\hline Short-term allowable strength $\mathrm{Pa}(\mathrm{kN})$ & 4.14 & 3.50 & 4.90 \\
\hline
\end{tabular}

*塑性率 $\mu$ *及び構造特性係数 Ds*は付録 2 )に示す方法により算出

Fig.10(a)は各変形角時の加力ループにおける 1 サイクル間の吸収 エネルギーの評価結果である。各試験体とも 1 ループ目と比較して 2 ループ目の值が低下していることが分かる。また、 2 ループ目の 各試験体の結果を比較すると合板耐力壁の結果が $1 / 30[\mathrm{rad}]$ を超え て大きく低下寸るのに対し、内挿型の両試験体では終局まで増加し 続ける結果となった。しかしながら Fig10(b)に示すように各振幅で の等価粘性減衰定数 heq 付䩮 3$)(2$ ループ目) は一般的な耐力壁と同様 に小さいままであり、減衰性能は大きくは改善されていない。

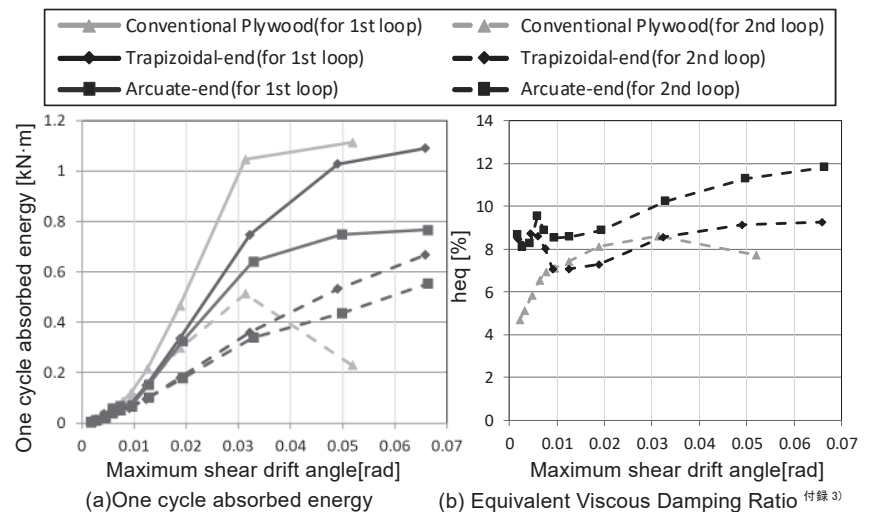

Fig.10 Comparison of damping capacities

\section{3. 摩擦機構内蔵による高減衰化}

\section{1 摩擦機構内蔵耐力壁の概要}

前章では面材を内挿型とすることによる高勒性化手法を示した。 本章ではこの面材内挿型の耐力壁内部にエネルギー吸収機構を設置 することでさらに高減衰化する手法を提案する。

Fig.11 に提案する耐力壁の概要図を示す。たて枠材と内挿パネル 
の間に摩擦機構(図中右上)を内蔵することで、壁の水平変形時(図中 (1) に発生するたて枠材と内挿パネル間の相対変位(図中(2) を利用 乙摩擦力(図中(3)によるエネルギー吸収性能を付与寸る仕組みとな っている。本摩擦機構には潤滑被膜処理を施した合金化溶融亜鉛め っき鋼板(GA)同士を、トルシア形高力ボルトで締め付けることによ って摩擦力(摩擦係数約 0.15 )を発揮する機構となっている。

Fig.12 に摩擦機構の単体性能評価試験付録 1)の結果を示す。本摩擦 機構が安定したバイリニア型の履歴ループを描き、高いエネルギー 吸収能力を有していることが分かる。

Fig.13 に耐力壁の構成詳細図を示す。摩擦機構の締付力導入に用 いる M16 トルシア形高力ボルトは、ピンテール部の破断溝の直径 を旋盤加工により細くすることで、ピンテール破断時の締付卜ルク を低減し、摩擦機構が発揮する摩擦力を適切に管理して用いた ${ }^{111}$ 。 また、ボルト締付軸力の低下抑制と変形時の復元力特性の安定化を 目的とし、ボルト軸部の直径と同じ口径を持つ中空鋼棒(外径 $32 \mathrm{~mm}$, 口径 $16.3 \mathrm{~mm}$, 長さ $20 \mathrm{~mm}$ )を緩み止めスペーサーとして用いている。

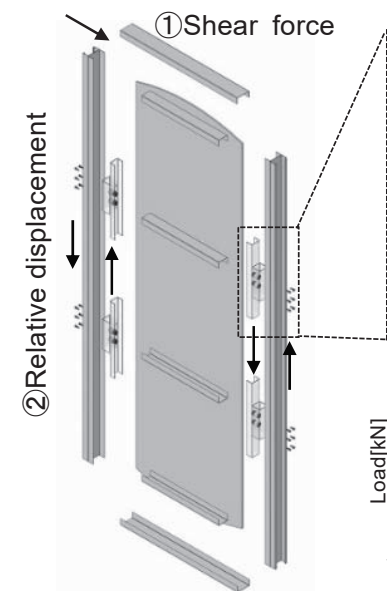
friction mechanism

Fig.12 Load-deflection relation of friction device
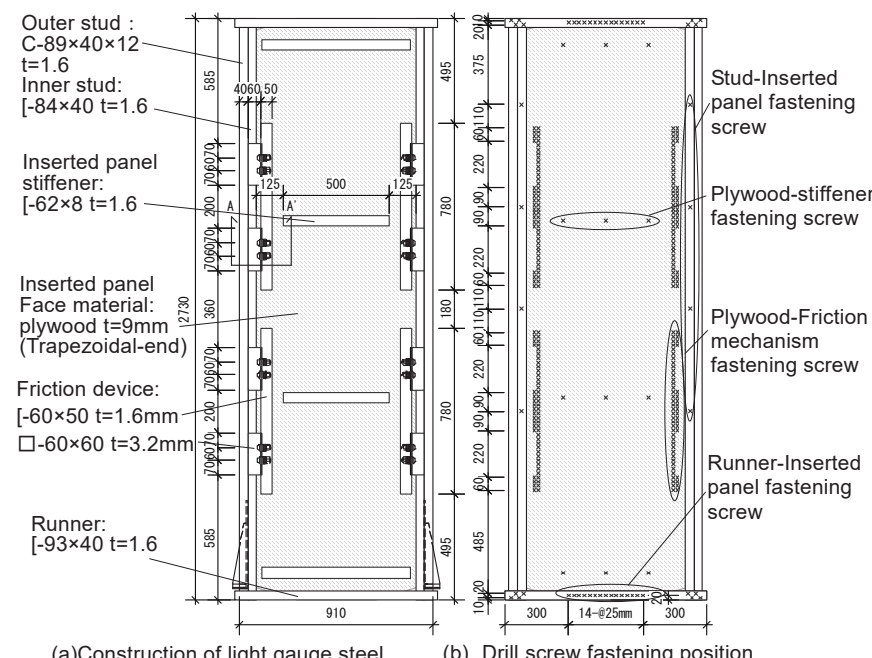

(a)Construction of light gauge stee

(b) Drill screw fastening position

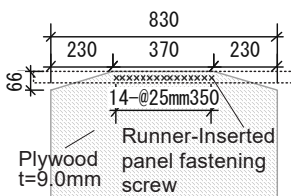

(c) Cut shape Inserted plywood

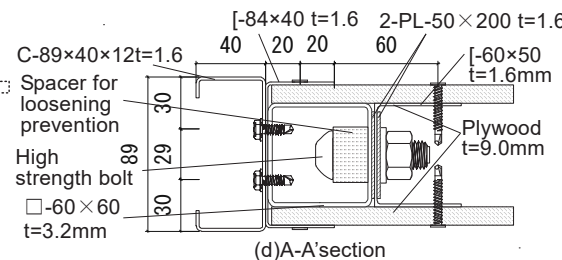

Fig.13 Details of specimen wall

\section{2 摩擦機構内蔵耐力壁の実大静的加力試験}

摩擦機構内蔵耐力壁の静的な力学的特性を加力試験により検討す る。試験システム・方法は 2.4 と同様である。Fig.14 に摩擦機構内 蔵耐力壁と従来型の合板耐力壁の荷重変形関係 12$)$ を重ねて示す。摩 擦機構内蔵耐力壁が合板耐力壁と比較して、極めて高い勒性とエネ ルギー吸収能力を発揮していることが分かる。Table 4 に荷重変形 関係の包絡線から算出した設計用特性值の一覧を示す。摩擦機構内 蔵耐力壁の最大耐力は合板耐力壁の 2 割り増し程度である一方で、 短期許容せん断耐力は 2 倍以上、構造特性係数 Ds は半分以下の数 值であり、金物等の接合部に過大な応力を発生させることなく壁数 を大幅に減少することが可能になる。Fig.15(a)は 1 サイクルエネル ギーの評価結果である。1 ループ目の結果を比較すると摩擦機構内 蔵耐力壁が合板耐力壁と比較して非常に高い值で推移し終局変形時 まで変形量にほぼ比例して増大し続けていることが分かる。また、 2 ループ目の結果においても、合板耐力壁が 1 ループ目と比較して 大きく低下するのに対し、摩擦機構内蔵耐力壁は 1 ループ目と同等 の值で推移している。Fig.15(b)は heq 付録 3) (2 ループ目)の評価結果 であり、摩擦機構内蔵耐力壁が合板耐力壁と比較して、小振幅から 大振幅に至るまで極めて高い減衰性能を有することが示されている。

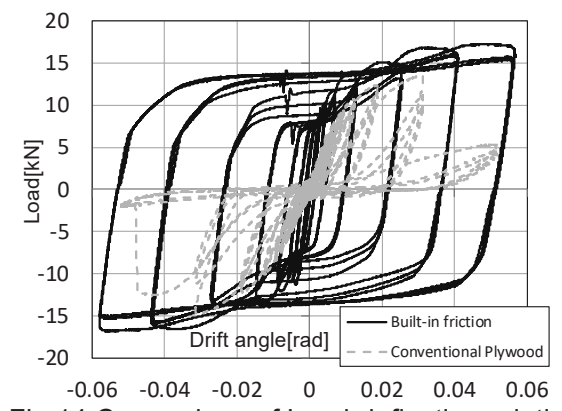

Fig.14 Comparison of Load-deflection relations

Table 4 Evaluation result of design characteristic value

\begin{tabular}{|l|r|r|}
\hline & Built-in friction & Conventional Plywood \\
\hline Maximum strength Pmax(kN) & 17.03 & 14.07 \\
\hline Yield strength Py(kN) & 11.10 & 8.11 \\
\hline Ultimate strength $\mathrm{Pu}(\mathrm{kN})$ & 15.50 & 12.66 \\
\hline Rigidity K(KN/rad) & 2633 & 1032 \\
\hline Ductility factor $\mu^{*}$ & 9.16 & 2.37 \\
\hline Ductility Reduction Factor Ds & 0.24 & 0.52 \\
\hline Pu.(0.2/Ds) $(\mathrm{kN})$ & 12.90 & 4.90 \\
\hline 2/3Pmax(kN) & 11.4 & 9.4 \\
\hline Strength at 1/200rad(kN) & 11.09 & 5.84 \\
\hline $\begin{array}{l}\text { Short-term allowable } \\
\text { strength } \mathrm{Pa}(\mathrm{kN})\end{array}$ & 11.10 & 4.90 \\
\hline
\end{tabular}

*塑性率 $\mu^{*}$ 及び構造特性係数 Ds*は付録 2)に示す方法により算出

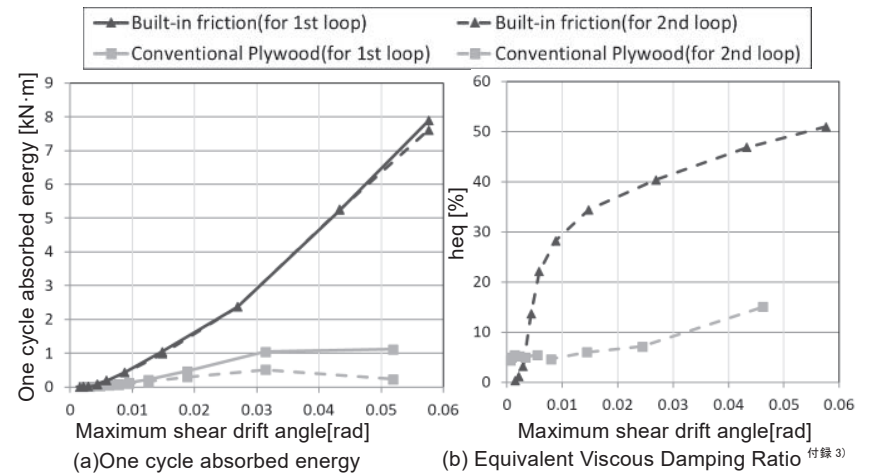

Fig.15 Comparison of damping capacities 


\section{3 摩擦機構内蔵耐力壁の振動台実験 ${ }^{10)}$}

摩擦機構内蔵耐力壁の動的な力学的特性を振動台実験により検討 する。Fig.16 に振動台実験の試験システムを示す。試験体下部は治 具を介して振動台上の鉄骨架台と、試験体上部は上部鉄骨梁と固定 した。試験体周囲の鉄骨フレームは試験体の面外方向への振動と上 部梁の回転を抑制し、リニアスライド上に支持された鍾の慣性力が 試験体の面内せん断力として作用寸る試験システムとなっている。 錘と周辺フレームの質量を合計した慣性力に寄与する質量の合計は $2.69[\mathrm{t}]$ となっており、試験体の短期許容せん断耐力に対する層せん 断力係数は 0.42 である。Table 5 に加振スケジュールを示す。全て の加振を同じ試験体で連続して実施した。まず加振番号 1〜 5 の試 験では、徐々に入力レベルを大きくすることで、最大応答層間変形 の増大と試験体各部の損傷状況の関係について検討した。加振番号 6 の加振にて試験体の最大応答層間変形が $1 / 30[\mathrm{rad}]$ を超え、一般的 な薄板軽量形鋼造耐力壁の安全限界変形を上回った。加振番号 7,8 では安全限界経験後の加振として、試験体が極大地震を経験した後 の強い余震を想定した加振を行った。その後入力エネルギーの極め て大きい地震動 3 波を順に入力し、試験体が終局変形に達するまで の特性を検討した。

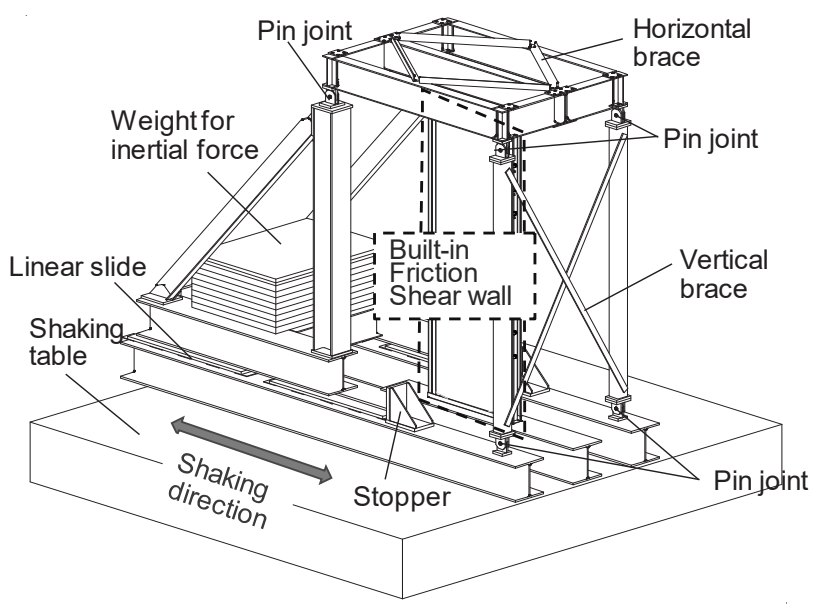

Fig.16 System for shaking table test of shear wall

Table 5 Input waves for shaking table test

\begin{tabular}{|c|c|c|c|c|c|}
\hline $\begin{array}{l}\text { Test } \\
\text { No }\end{array}$ & $\begin{array}{c}\text { Earthquake name } \\
\text { Observational component } \\
\text { Phase } \\
\end{array}$ & $\begin{array}{l}\text { Normalization } \\
\text { magnification }\end{array}$ & $\begin{array}{l}\text { PGD } \\
{[\mathrm{mm}]}\end{array}$ & $\begin{array}{c}\text { PGV } \\
{[\mathrm{cm} / \mathrm{s}]}\end{array}$ & $\begin{array}{c}P G A \\
{\left[\mathrm{~cm} / \mathrm{s}^{2}\right]}\end{array}$ \\
\hline 1 & $\begin{array}{c}\text { Public announced wave } \\
\text { Random phase }\end{array}$ & Lv1 & 145 & 16 & 170 \\
\hline 2 & \multirow{5}{*}{$\begin{array}{c}\text { The } 2011 \text { off the Pacific } \\
\text { coast of Tohoku Earthquake } \\
\text { Haga_EW }\end{array}$} & 0.2 & 43 & 14 & 376 \\
\hline 3 & & 0.4 & 86 & 26 & 708 \\
\hline 4 & & 0.6 & 130 & 39 & 769 \\
\hline 5 & & 0.8 & 173 & 52 & 829 \\
\hline 6 & & 1.0 & 216 & 66 & 923 \\
\hline 7 & \multirow{2}{*}{$\begin{array}{c}\text { Public announced wave } \\
\text { Random phase }\end{array}$} & Lv1 & 145 & 16 & 225 \\
\hline 8 & & Lv2 & 458 & 80 & 652 \\
\hline 9 & $\begin{array}{c}\text { The } 2004 \text { Mid Niigata } \\
\text { Prefecture Earthquake } \\
\text { Takezawa_EW } \\
\end{array}$ & 1.0 & 313 & 79 & 675 \\
\hline 10 & $\begin{array}{c}\text { The } 2011 \text { off the Pacific } \\
\text { coast of Tohoku Earthquake } \\
\text { Haga_EW }\end{array}$ & 1.0 & 216 & 66 & 868 \\
\hline 11 & $\begin{array}{c}\text { The } 2004 \text { Mid Niigata } \\
\text { Prefecture Earthquake } \\
\text { Ojiya_EW }\end{array}$ & 1.0 & 296 & 124 & 1067 \\
\hline
\end{tabular}

Fig.17 に各地震動入力時の荷重変形関係を示す。層せん断荷重は 試験体上部で計測した加速度に、試験体重量（2.68[t]）を乗じるこ とにより算出した。

どの地震動入力に対しても静的加力試験と同様に安定したバイリ ニア型の復元力特性を示し、高いエネルギー吸収能力を発揮してい ることが分かる。(b)の結果は安全限界変形を経験する前後の同一地 震波に対する応答の比較である。安全限界を経験後の荷重変形関係 では若干の剛性及び耐力の低下が生じており、応答変形が増大して いることが分かる。摩擦機構部のボルト締付力が低下し摩擦力が低 下したことと、ドリルねじ接合部めり込みによる耐力低下が原因で あると考えられる。(c)は最終加振時(TestNo.11)の荷重変形関係であ り、1/15[rad]を超える応答となっているが、依然として高い耐力と 安定したエネルギー吸収能力を発揮しており、摩擦機構内蔵耐力壁 が繰り返しの地震動入力に対しても高い勒性と減衰力を維持し続け る性能を有していることを確認することが出来る。
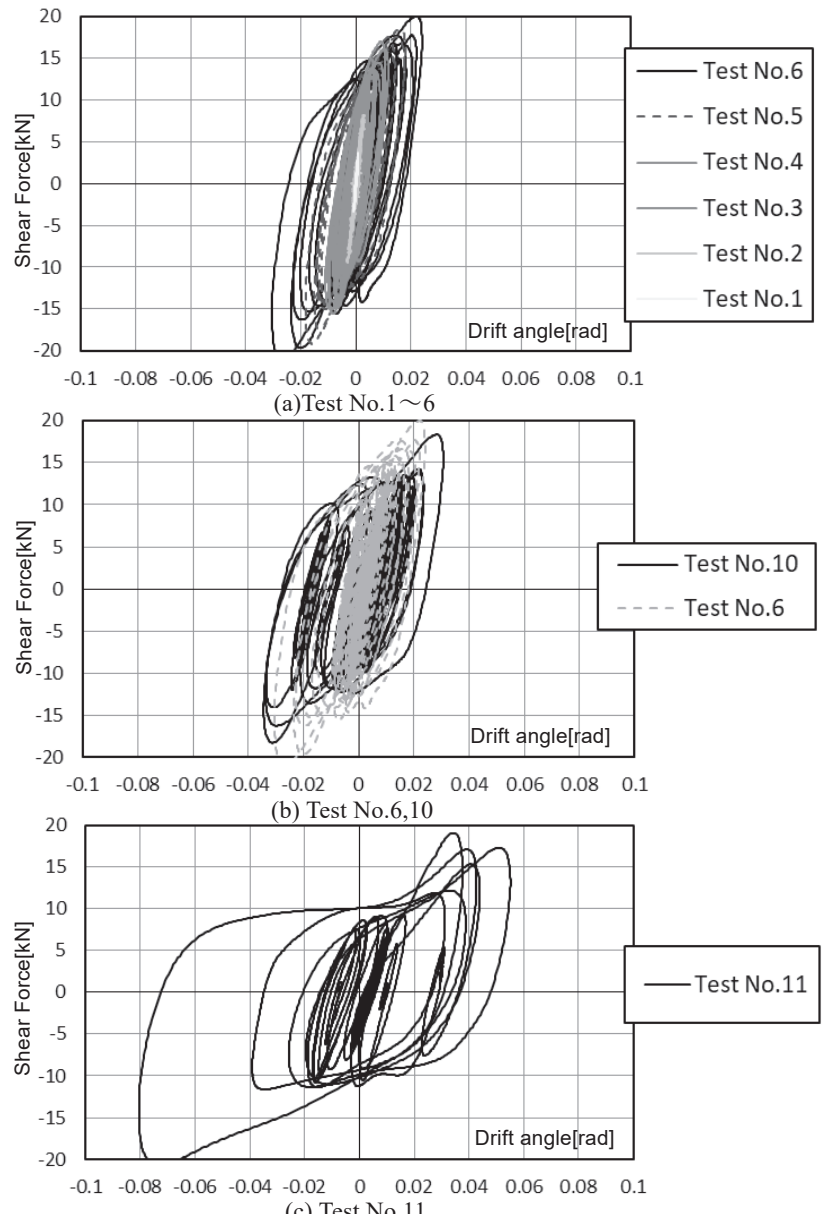

(c) Test No.11

Fig.17 Load-deflection relations by shaking table tests

4. 摩擦機構内蔵耐力壁を適用した 2 層建物モデルの耐震性能の検討 本章では地震応答解析を用いて、摩擦機構内蔵耐力壁を適用して設 計した 2 層建物モデルが有する耐震性を、一般的な合板耐力壁を適 用した建物モデルと比較し検討する。

\section{1 各耐力壁の復元力特性のモデル化}

地震応答解析を行うに当たり一般的な薄板軽量形鋼造耐力壁であ る合板耐力壁((a)Plywood wall)と、せっこうボード耐力壁 
((b)Gypsum wall)の実験結果 ${ }^{12}$ ) と、3.2 で示した摩擦機構内蔵耐力 壁((C)Built-in friction wall)の実験結果より、その復元力特性を 拡張 NCL モデル 13)を用いてモデル化した。Fig.18 に実験結果と作 成した解析モデルによる荷重変形関係の比較を示す。各耐力壁とも スケルトンカーブ及び固有ループ共に精度良く模擬していることが 分かる。

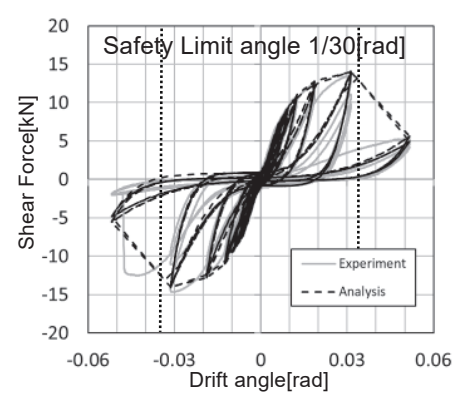

(a)Plywood wall

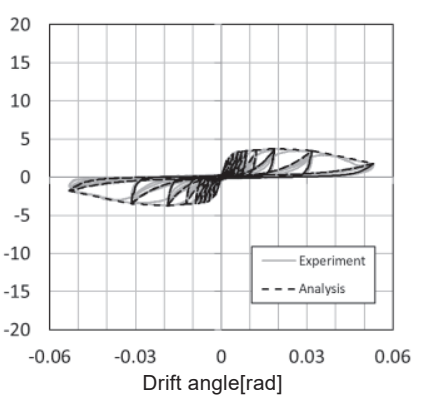

(b)Gypsum wall

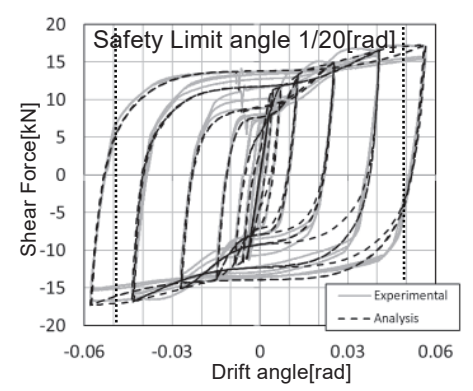

(C)Built-in friction wall

Fig.18 Comparison of load-deflection relation by test with by analysis

\section{2 解析方針}

2 階建て建築物を対象に合板耐力壁を適用して設計したモデル (以下、合板モデル) と摩擦機構内蔵耐力壁を適用して設計したモデ ル(以下、摩擦モデル)の応答を比較し検討寸る。解析は Fig.19に示 すように 2 質点のせん断質点系モデルにより行い、各階の質量は各 階床面積が $70\left[\mathrm{~m}^{2}\right]$ 程度の一般的な戸建て住宅を想定し設定した耐 力壁の $1 \mathrm{P}$ 当たりの設計值は Table 6 に示す通りで、両モデルとも 内装側面材としてせっこうボード耐力壁(片面)を、合板又は摩擦機 構内蔵耐力壁と常に同数組み合わせて設計に用いることとした。各 層の耐力壁の数量は $\mathrm{Ai}$ 分布に基づく設計用せん断力の分布に比例 させて配置するものとし、固有周期 $\mathrm{T}$ は 0.2 秒 $(\mathrm{T}=0.03 \mathrm{H})$ 、地域係 数 $\mathrm{Z}$ 及び振動特性係数 Rt は共に 1.0 とした。減衰定数 $\mathrm{h}$ は $5 \%$ (瞬 間剛性比例型 $)$ し、時間刻みは 0.002 秒で、Newmark- $B$ 法( $(B=1 / 4)$ によって解析を行った。入力地震波は付録 3)に示寸最大速度が $50[\mathrm{~cm} / \mathrm{s}]$ を超える代表的な観測地震動 32 波とした。初めに、耐震等 級 3 相当 $\left(\mathrm{C}_{0}=0.3 \times 1.5\right)$ となるように設計した両モデルについての解 析を行いその応答を比較検討した。次に、建築基準法(ルート 1)を満 たすために最低限必要な壁数の $10 \%$ を有するモデルについて解析 を行い、何れかの層の最大応答層間変形角が各モデルの安全限界変 形角(合板モデル:1/30[rad]、摩擦モデル: $1 / 20[\mathrm{rad}])$ を回る場合に はさらに各層の壁数を $10 \%$ 増加するという操作を繰り返すことで、 各入力地震波に対して何れの層でもその最大応答が安全限界を下回 るために必要な壁数を求めた。
$6.81 \times 10^{3}[\mathrm{~kg}]$

Table 6 Design characteristic values

(Basic unit : 1P(910mm))

$11.09 \times 10^{3}[\mathrm{~kg}]$

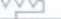

Fig.19 2-story lumped-mass model

\begin{tabular}{|l|r|r|r|r|}
\hline Model name & \multicolumn{2}{|c|}{ Plywood model } & \multicolumn{2}{|c|}{ Friction model } \\
\hline Shear wall & $\begin{array}{l}\text { Plywood } \\
\text { wall }\end{array}$ & $\begin{array}{l}\text { Gypsum } \\
\text { wall }\end{array}$ & $\begin{array}{l}\text { Built-in } \\
\text { friction }\end{array}$ & $\begin{array}{l}\text { Gypsum } \\
\text { wall }\end{array}$ \\
\hline $\begin{array}{l}\text { Short-term } \\
\text { allowable } \\
\text { strength } \mathrm{Pa}(\mathrm{kN})\end{array}$ & 4.9 & 2.05 & 11.1 & 2.05 \\
\hline
\end{tabular}

\section{3 解析結果}

\section{3.1 耐震等級 3 モデルの壁数・応答比較}

ルート 1 の耐震設計において等級 3 となるように設計した建物モ デルについての比較検討を行う。Table 7 に合板モデル(表中 Plywood model) と摩擦モデル(表中 Friction model)において、耐震 等級 3 とするために最低限必要な各層の壁の数量を示す。摩擦モデ ルの壁数は合板モデルの約半分となっており、摩擦機構内蔵耐力壁 を用いることで大幅に壁の数量を減らした設計が可能となることを 示している。Fig. 20 は各地震波入力時の最大層間変形角を比較した 結果である。合板モデルでは 32 波中 14 のケースで安全限界変形角 を上回るのに対し、摩擦モデルでは 6 ケースに留まっている。Fig.21 は chokubetsu_ew 波入力時の各層の荷重変形関係を重祆て示した 結果である。合板モデルでは 2 層の変形が 1 層を大きく上回り安全 限界を超えるのに対し、摩擦モデルでは 1 層のバイリニア型の復元 力特性が大きくエネルギー吸収をすることで 2 層の応答が抑制され ていることが分かる。

Table 7 Number of walls corresponding to seismic grade 3 [×1P $(910 \mathrm{~mm})]$

\begin{tabular}{|l|r|r|r|}
\hline Model name & \multicolumn{1}{|c|}{$1 \mathrm{~F}$} & \multicolumn{1}{c|}{$2 \mathrm{~F}$} & \multicolumn{1}{c|}{ Total } \\
\hline \hline Plywood model & 11.4 & 5.6 & 17.0 \\
\hline Friction model & 6.0 & 3.0 & 9.0 \\
\hline
\end{tabular}

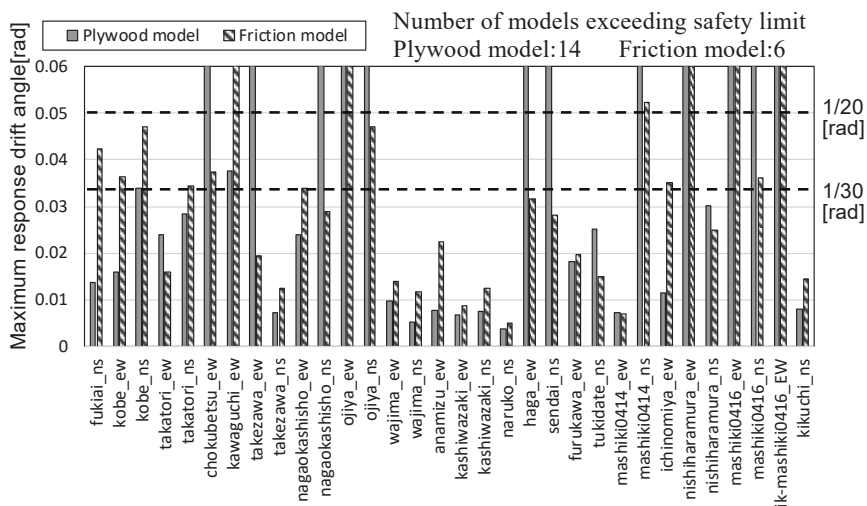

Fig.20 Comparison of the maximum responses of shear drift angle (Seismic grade 3 )

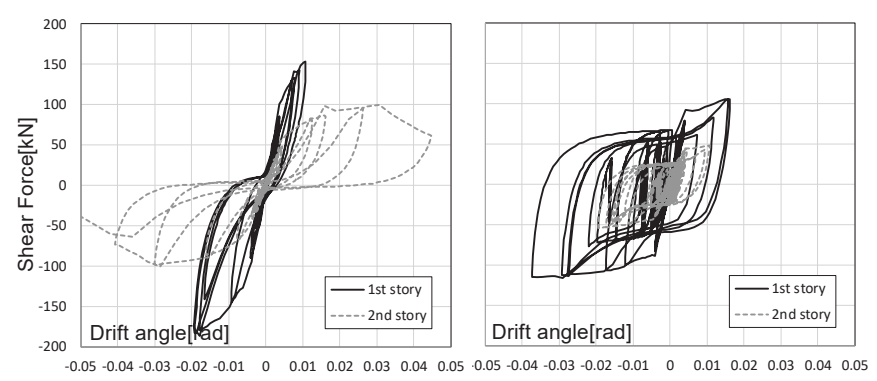

(a)Plywood model $\quad$ (b)Friction model

Fig.21 Load-deflection relations by analysis[input wave: chokubetsu_ew] 


\section{3. 2 安全限界を下回るのに必要な壁数の検討と応答の比較}

Fig. 22 は各入力地震波に対して、全ての層の最大応答層間変形角 が安全限界変形角を下回るために必要な 1 層の壁数を比較した結果 である。合板モデルの壁数は全ての入力地震波に対して摩擦モデル を上回っており、合板モデルの応答を安全限界変形以下とするため には摩擦モデルの概放 2 倍以上の壁数が必要であることが分かる。

Fig.23 は応答が安全限界変形以下となった各モデルの最大応答 加速度を比較した結果である。合板モデルの応答は全て摩擦モデル を上回っており、合板モデルでは最大で $4000[\mathrm{Gal}]$ を超える応答加 速度が生じるのに対し、摩擦モデルでは全て $1000[\mathrm{Gal}$ 以下の応答 に抑制される結果となった。なお、本検討はルート 1 によるもので あるが、各耐力壁の短期許容耐力 $\mathrm{Pa}$ の評価において $\mathrm{Pu} ・(0.2 / \mathrm{Ds})$ が含まれているため、ルート 3 による検討を行った場合においても 剛性率・偏心率が極端な值とならない限り同様の結果となる。

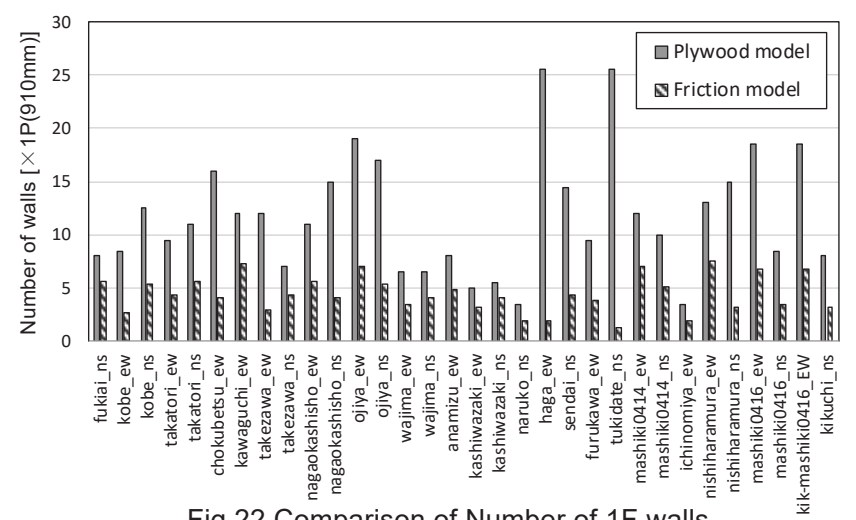

Fig.22 Comparison of Number of $1 \mathrm{~F}$ walls required for the response within the safety limit

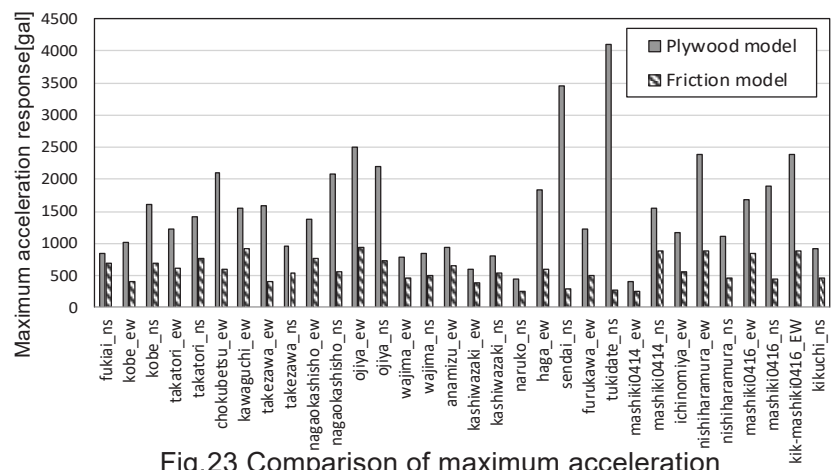

5. まとめ

本報では薄板軽量形鋼造耐力壁の高勒性化及び高減衰化手法を 提案すると共に、その基本力学特性を実験的に明らかにした。また、 提案する摩擦機構内蔵耐力壁を 2 層建物モデルに適用した場合の耐 震性に関する検討を解析によって行った。

本研究によって得られた知見を以下に示す。

1)耐力壁面材を周辺フレームである薄板軽量形鋼朹材の内側に挿入 し、ドリルねじ頭側に鋼板が配置されるように留め付けることで、 ドリルねじ接合部のパンチング破壊と面材の脱落を抑止することが 出来るため耐力壁の高勒性化が可能である。

2)面材内挿型の耐力壁のたて枠と内挿パネル間に潤滑被膜処理を施
した合金化溶融亜鉛めっき鋼板同士を高力ボルトで締め付けた摩擦 機構を設置することで、壁変形時に当該部分に生じる相対変形を利 用しエネルギー吸収能力を大幅に向上できることを明らかにした。 3)摩擦機構を内蔵した実大耐力壁の静的加力試験を実施し、従来の 合板耐力壁と比較して極めて高い勒性とエネルギー吸収能力を発揮 することを示した。

4)摩擦機構内蔵耐力壁の実大振動台実験を実施し、動的な地震動入 力時にも静的試験の結果と同様に高い勒性とエネルギー吸収能力を 発揮することが分かった。また極大レベルの地震動入力の繰り返し に対しても、高い勒性と減衰力を維持し続ける性能を有することが 明らかとなった。

5)摩擦機構内蔵耐力壁を適用した 2 層建物モデルの耐震性を地震応 答解析により検討した結果、基準法で想定する範囲を超える強い地 震動入力に対しても安全性を確保するために必要な壁数は、従来の 合板を耐力壁とする建物モデルの半分以下であり、かつその際に発 生する最大応答加速度も大幅に抑制可能であることが分かった。

本研究では提案する摩機構内蔵耐力壁の力学的な特性につき、概 念的な検討結果を中心として報告した。施工性を考慮した詳細設計 を反映させての適用性の検討結果は次報にて報告の予定である。

\section{謝辞}

本研究は早稲田大学理工学研究所プロジェクト研究「建築物の構 造デザイン技術の高度化」の一環で、社団法人日本鉄鋼連盟平成 28 年度鋼構造研究・教育助成事業(代表 曽田五月也) を受けて行った。 また、研究の実施にあたり高橋宏幸君、中原政人君、久保和民君、 京田隆寛君、斎藤健寞君 (元早稲田大学曽田研究室大学院生) の協力 を得た。ここに記して謝意を表す。

\section{付録 1) 摩擦機構の単体性能評価試験}

摩擦機構単体の力学的特性を把握するために単体性能試験を実施した。試 験体は摩擦機構のボルト 2 本分の締付部である。Ex.Fig.1 に試験システム図 を示す。加力は変位制御にて Ex.Table 1 に示すように耐力壁試験時の摩擦機 構部変形に相当する各変形を入力值として、0.2Hzの正弦波 3 回繰り返しにて 行った。実験結果の荷重変形関係を本文中 Fig.12 に示す。

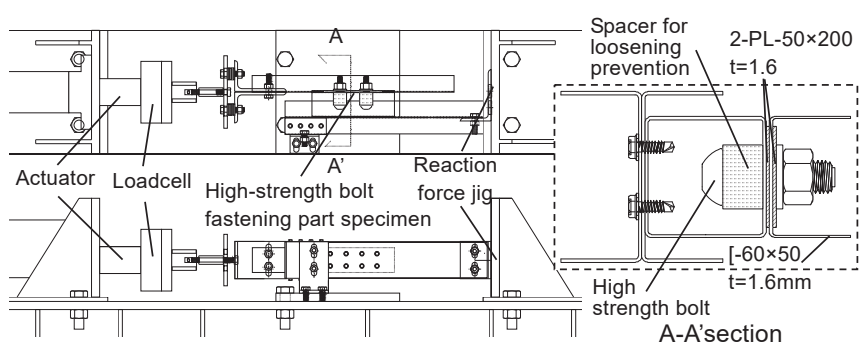

Ex.Fig. 1 Loading system of friction device test

Ex.Table 1 Input deformation of test

\begin{tabular}{|l|c|c|c|c|c|c|c|c|c|}
\hline $\begin{array}{l}\text { Drift angle of shear } \\
\text { wall[rad] }\end{array}$ & $1 / 300$ & $1 / 200$ & $1 / 150$ & $1 / 00$ & $1 / 75$ & $1 / 50$ & $1 / 30$ & $1 / 20$ & $1 / 15$ \\
\hline $\begin{array}{l}\text { Deformation of } \\
\text { friction device[mm] }\end{array}$ & 1.4 & 2.1 & 2.8 & 4.2 & 5.6 & 8.3 & 13.9 & 20.9 & 27.8 \\
\hline
\end{tabular}




\section{付録 2) 履歴ループ面積を考慮した構造特性係数 Ds の評価法}

文献 1)14)で示される方法に従い、履歴ループの面積を考慮して低減した塑性 率 $(\mu)$ により Ds を算出する。算出式を式(a)と式(b)に示す。

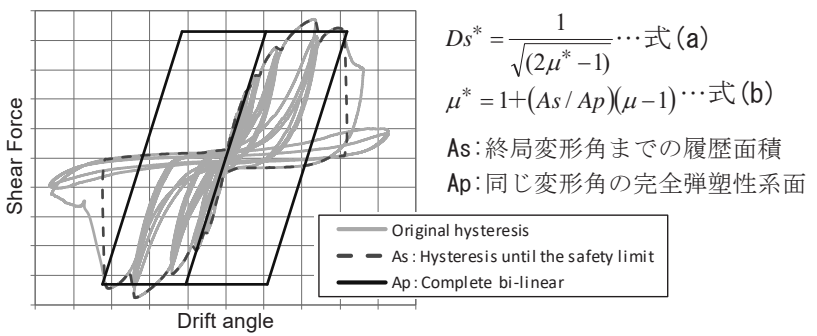

Ex.Fig.2 Diagram to calculate the area of hysteresis

\section{付録 3) 等価粘性減衰定数 $h_{\mathrm{eq}}$ の評価 ${ }^{15}$}

繰り返し加力実験によって得られた履歴ループを用いて各ループごとの減 衰性能を等価粘性減衰定数 heq によって評価した。算出式を式(C)に示寸。

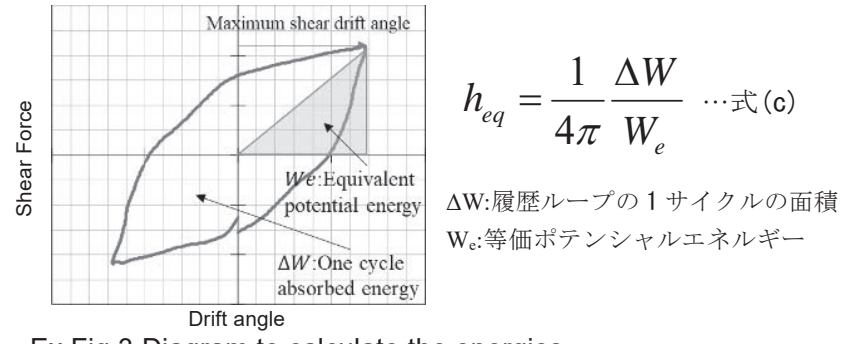

Ex.Fig.3 Diagram to calculate the energies

\section{付録 4) 解析に用いた入力地震動}

本報では国内の代表的な観測地震動記録のうち最大速度が $50[\mathrm{~cm} / \mathrm{s}]$ を超え

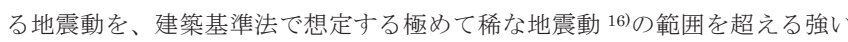
地震動として解析に用いることとした。Ex.table 2 に解析に用いた 32 の地震 波の諸元を示す。

Ex.table 2 Specifications of input seismic waves

\begin{tabular}{|c|c|c|c|c|}
\hline $\begin{array}{c}\text { Year of } \\
\text { occurrence }\end{array}$ & Earthquake name & $\begin{array}{c}\text { Observation } \\
\text { area_direction }\end{array}$ & $\begin{array}{l}\text { PGV } \\
\text { (kine) }\end{array}$ & $\begin{array}{l}\text { PGA } \\
\text { (gal) }\end{array}$ \\
\hline \multirow{5}{*}{1995} & \multirow{5}{*}{$\begin{array}{l}\text { The Southern Hyogo } \\
\text { Prefecture Earthquake } \\
\text { 兵庫県南部地震 }\end{array}$} & fukiai_ns & 126 & 810 \\
\hline & & kobe ew & 72 & 619 \\
\hline & & kobe_ns & 83 & 821 \\
\hline & & takatoriew & 128 & 666 \\
\hline & & takatorins & 134 & 642 \\
\hline 2003 & $\begin{array}{c}\text { The Tokachi-oki } \\
\text { Earthquake十勝沖地震 }\end{array}$ & chokubetsu_ew & 112 & 785 \\
\hline \multirow{7}{*}{2004} & \multirow{7}{*}{$\begin{array}{c}\text { The Mid Niigata Prefecture } \\
\text { Earthquake } \\
\text { 新潟県中越地震 }\end{array}$} & kawaguchi_ew & 133 & 1676 \\
\hline & & takezawa_ew & 89 & 722 \\
\hline & & takezawans & 101 & 538 \\
\hline & & nagaokashisho_ew & 120 & 706 \\
\hline & & nagaokashisho_ns & 111 & 870 \\
\hline & & ojiya_ew & 130 & 1308 \\
\hline & & ojiya_ns & 96 & 1147 \\
\hline \multirow{3}{*}{2007} & \multirow{3}{*}{$\begin{array}{c}\text { The Noto Hanto Earthquake } \\
\text { 能登半島地震 }\end{array}$} & wajima_ew & 77 & 439 \\
\hline & & wajima_ns & 98 & 464 \\
\hline & & anamizu_ew & 99 & 782 \\
\hline & The Niigataken Chuetsu-oki & kashiwazakiew & 80 & 514 \\
\hline 2007 & $\begin{array}{c}\text { Earthquake } \\
\text { 新潟県中越沖地震 }\end{array}$ & kashiwazaki_ns & 129 & 667 \\
\hline 2008 & $\begin{array}{c}\text { The Iwate-Miyagi Nairiku } \\
\text { Earthquake } \\
\text { 岩手·宮城内陸地震 }\end{array}$ & naruko_ns & 79 & 440 \\
\hline
\end{tabular}

\begin{tabular}{|c|c|c|c|c|}
\hline $\begin{array}{c}\text { Year of } \\
\text { occurrence } \\
\end{array}$ & Earthquake name & $\begin{array}{c}\text { Observation } \\
\text { area_direction }\end{array}$ & $\begin{array}{c}\text { PGV } \\
\text { (kine) }\end{array}$ & $\begin{array}{l}\text { PGA } \\
\text { (gal) } \\
\end{array}$ \\
\hline \multirow{4}{*}{2011} & \multirow{4}{*}{$\begin{array}{l}\text { The } 2011 \text { off the Pacific } \\
\text { coast of Tohoku Earthquake } \\
\text { 東北地方太平洋沖地震 }\end{array}$} & haga_ew & 78 & 1197 \\
\hline & & \begin{tabular}{|l} 
sendai_ns \\
\end{tabular} & 84 & 1517 \\
\hline & & furukawa ew & 88 & 572 \\
\hline & & tukidate_ns & 117 & 2700 \\
\hline \multirow{9}{*}{2016} & \multirow{2}{*}{$\begin{array}{c}\text { The } 2016 \text { Kumamoto } \\
\text { Earthquake 熊本地震 }(4 / 14)\end{array}$} & mashiki0414_ew & 133 & 729 \\
\hline & & mashiki0414_ns & 112 & 632 \\
\hline & \multirow{7}{*}{$\begin{array}{c}\text { The } 2016 \text { Kumamoto } \\
\text { Earthquake } \\
\text { 熊本地震 }(4 / 16)\end{array}$} & ichinomiya_ew & 72 & 294 \\
\hline & & nishiharamura_ew & 214 & 770 \\
\hline & & nishiharamura_ns & 91 & 628 \\
\hline & & mashiki0416 ew & 183 & 825 \\
\hline & & mashiki0416 ns & 81 & 573 \\
\hline & & kik-mashiki0416_EW & 126 & 1157 \\
\hline & & kikuchi_ns & 55 & 429 \\
\hline
\end{tabular}

\section{参考文献}

1)The Japan Iron and Steel Federation: Guidebook on cold-formed steel frame structure design second edition, Gihodo publishing, 2014(in Japanese)

(社) 日本鉄鋼連盟：薄板軽量形鋼造建築物設計の手引き 第 2 版，技報堂出 版出版,2014

2)Karatsu Toshikazu et al.: In-Face Shearing Test of Bearing Walls -Test Results- : Study on Properties of Steel-Framed Houses (Part2), Summaries of Technical Papers of Annual Meeting, Architectural Institute of Japan ,C-1, pp.981-982, 1998(in Japanese)

唐津敏一，宮尾俊明，高木伸之，河合良道，清水秀夫：スチールハウス 耐力壁の基準耐力を求める面内せん断試験, -試験結果-スチールハウスの諸 性能に関寸る研究 その 2 , 日本建築学会大会学術講演梗概集, C-1, pp.981-982, 1998

3)Kawai Yoshimichi et al.: Study on Performances of KC-TYPE Steel-Framed Houses : Part 4 Seismic Analysis with Resistance Degrading by Cyclic Loading, Summaries of Technical Papers of Annual Meeting, Architectural Institute of Japan , C-1, pp.1035-1036, 2000(in Japanese)

河合良道，菅野良一，二宮淳，高木伸之:繰返し荷重による耐力低下を考 慮した地震応答解析, $\mathrm{KC}$ 型スチールハウスの性能に関する研究 その 4, 日 本建築学会大会学術講演梗概集， C-1， pp.1035-1036, 2000 4)Ikeda Katsutoshi et al.: STUDY ON SEISMIC ENERGY RESPONSE OF STEEL-FRAMED HOUSINGS, Journal of Structural and Construction Engineering (Transactions of AIJ) , Vol. 68 , No. 566, pp.137-144, 2003.4(in Japanese)

池田勝利，青木博文：スチールハウス構造体の地震入力エネルギ吸収性能 に関する研究, 日本建築学会構造系論文集, 第 68 巻, 第 566 巻, pp.137-144, 2003.4

5)Kanno Ryoichi et al.: Shaking Table Test of Steel Framed Walls : Study on Various Performance on Steel Framed Houses Part7, Summaries of Technical Papers of Annual Meeting, Architectural Institute of Japan , C-1, pp.991-992, 1998(in Japanese)

菅野良一，作本 好文，宮尾 俊明，二宮 淳，河合 直人，藤本 効：又 チールハウス耐力壁の振動台試験 スチールハウスの諸性能に関する研究 その 7, 日本建築学会大会学術講演梗概集, C-1, pp.991-992, 1998

6)Ministry of Land, Infrastructure and Transport Notification No. 1641: To determine technical standards necessary for safety concerning the construction method of the structural parts of buildings or buildings of cold-formed steel frame structure construction etc. 2012.9(in Japanese) 国土交通省告示第 1641 号: 薄板軽量形鋼造建築物の建築物又は建築物の 構造部分の構造方法に関する安全上必要な技術的基準を定める等の件, 2012.9

7)Soda Satsuya et al.: Seismic design of steel house with ductile load-bearing panel : Part one: Cyclic loading test on full-scale panels, Summaries of Technical Papers of Annual Meeting, Architectural Institute of Japan, structureIII, pp.873-874,2012,8(in Japanese) 曽田五月也, 青野裕太, 中原政人：薄板軽量形鋼造耐力パネルの高勒性化 に関する研究，その 1 . 実大耐力パネルの正負交番繰り返し載荷試験, 日本 建築学会大会学術講演梗概集, 構造III, pp 873-874, 2012

8)Soda Satsuya et al.: Study on High Damping Steel House : Part1. Repetitive loading tests on full-scale bearing wall, Summaries of 
Technical Papers of Annual Meeting, Architectural Institute of Japan, structureIII, pp.873-874,2013,8(in Japanese)

曽田五月也，久保和民，中原政人：薄板軽量形鋼造の高減衰化に関する研

究：その 1. 実大耐力壁の正負交番繰り返し載荷試験, 日本建築学会大会学 術講演梗概集, 構造III, pp 873-874, 2013.8

9)Soda Satsuya et al.: Development of High-Ductility and High-Damping Bearing Walls for Medium-Rise Steel Houses : Part2. Design of medium-rise steel house and seismic performance estimation of seismic response analysis, Summaries of Technical Papers of Annual Meeting, Architectural Institute of Japan, structureIII, pp.1153-1154, 2015,9(in Japanese)

曽田五月也，久保和民，齋藤健寛：高靭性・高減衰耐力壁を用いた薄板軽量 形鋼造の中層化に関する研究,その 1 . 実大耐力壁の正負交番繰り返し載荷 試験, 日本建築学会大会学術講演梗概集, 構造III, pp.1153-1154, 2015,9

10)Oiwa Nao et al.: Development of High-Ductility, High-Damping and High-Strength Steel Houses Part1. Shaking table tests on full-scale bearing wall, Summaries of Technical Papers of Annual Meeting, Architectural Institute of Japan, structureIII, pp.845-846, 2016 (in Japanese)

大岩奈央, 曽田五月也, 脇田健裕, 京田隆寛, 齋藤健寛, 高靭性 - 高減衰 高耐力型薄板軽量形鋼造建築物の開発, その 1 . 実大耐力壁を用いた振動台 実験, 日本建築学会大会学術講演梗概集, 構造III, pp.845-846, 2016

11)Oiwa Nao et al.: Development of High-Ductility, High-Damping and High-Strength Steel Houses, Part6. Control Methods for tightening axial force of Torque Shear Type High Power Bolt using for frictional force introduction, Summaries of Technical Papers of Annual Meeting, Architectural Institute of Japan, structureIII, pp.1117-1118, 2017 (in Japanese)

大岩奈央, 曾田五月也, 脇田健裕, 斎藤健寛, 菅原良太：高勒性・高減衰 高耐力型薄板軽量形鋼造建築物の開発，その 6 . 摩擦力導入に用いるトル シア形高力ボルトの締付軸力管理, 日本建築学会大会学術講演梗概集, 構 造III, pp.1117-1118, 2017

12)Wakita Takehiro et al.: Experimental Study on High Performance Hybrid Structural System for Steel Frame House : Part1 Comparison of Different Bearing Walls, Summaries of Technical Papers of Annual Meeting, Architectural Institute of Japan, structureIII, pp.839-840,2009 (in Japanese)

脇田健裕,安達旭宏, 曽田五月也：高性能ハイブリッド型スチールハウスの 開発に関する実験, その 1 各種スチールハウス用耐力壁の比較, 日本建築 学会大会学術講演梗概集, 構造III, pp.839-840, 2009

13)Matsunaga Hiroki et al.: A UNIVERSAL MODELING METHOD FOR WOODEN SHEAR/NONSHEAR WALLS, Journal of Structural and Construction Engineering (Transactions of AIJ), Vol.74, No. 639, pp.889-896, 2009.5(in Japanese)

松永裕樹, 宮津裕次, 曽田五月也: 木造軸組耐力壁/非耐力壁の汎用モデル 化手法に関寸る研究, 日本建築学会構造系論文集, 第 74 巻, 第 639 号, pp.889-896,2009.5

14)The building center of Japan: Evaluation method of horizontal load capacity of building and allowable stress degree of building, building letter, pp.39 42, 2002.3(in Japanese)

日本建築センター:建築物の保有水平耐力及び部材の許容応力度の評価方 法,ビルディングレター, pp.39〜42, 2002.3

15)Shibata Akinori: Dynamic Analysis of Earthquake Resistant Structures, Morikita Publishing CO., LTD,2014 (in Japanese) 柴田明徳: 最新而震構造解析 第 3 版, 森北出版株式会社, 2014

16)The building center of Japan:Time history response analysis Building performance evaluation business method manual, 2000 (in Japanese) 日本建築センター: 時刻歴応答解析建築物性能評価業務方法書, 2000 


\title{
DEVELOPMENT OF HIGH-DUCTILITY HIGH-DAMPING SHEAR WALL FOR STEEL FRAMED HOUSE AND ITS BASIC MECHANICAL PROPERTIES
}

\author{
Satsuya SODA* and Takehiro WAKITA** \\ * Prof., Dept. of Architecture, Waseda University, Dr.Eng. \\ ** Assist. Prof., RISE, Waseda University, Dr.Eng.
}

\begin{abstract}
A steel framed house consists of walls and floors made by panels that plywood boards and light-gauge cold-formed steel frames are fastened with drill screws. Seismic performance of steel framed houses mainly depends on force-deformation relation of shear walls. Most conventional plywood shear walls show poor ductility because they may suddenly lose strength triggered by the break of the screw or punching out of the board when deflection angle becomes around $1 / 30[\mathrm{rad}]$. Therefore the energy absorbing ability of this wall is very low because of its pinching property in load-deflection relations. Since Japan is an earthquake prone country, the use of steel framed houses has been limited to three story buildings until recent years. But the revision of the design code in 2012 made it possible to apply the structure to a medium-rise building up to four stories. However, when we want to build a four-story house using conventional plywood shear walls, the amount of walls often becomes too much, spoiling the flexibility of the construction. In addition, it is a big problem that response acceleration and stress acting on specific parts of a house will become excessive.
\end{abstract}

In this paper, we first proposed a method of inserting plywood inside the peripheral frames consist of the light-gauge cold-formed steels and fastening it with drill screws. By using this method, it is possible to prevent the punching failure of drill screw joints and the dropout of the plywood. As a result, it was shown by static loading test that the ductility of this shear wall is improved.

Then, we proposed a method to install friction devices that consist of lubricated coated galvanized steel tightened with high-strength bolts between the studs and the inserted panel. This method is intended to make use of energy absorption by frictional force caused by the relative deflection generated between the studs and inserted panel. We conducted a number of the static loading tests on this built-in friction mechanism shear wall and found that it has very high ductility and damping capacity compared with conventional plywood shear wall. As a result of the shaking table tests, it is also confirmed that the wall can hold a stable energy absorbing capacity even when subject to repetition of large amplitude ground motions.

Finally, we investigated the seismic performance of 2 -story house models designed with built-in friction mechanism shear walls by earthquake response analyses. In this analytical study, we used seismic waves recorded in Japan with the maximum speed over $50[\mathrm{~cm} / \mathrm{sec}]$ as waves exceeding the level required by seismic design regulations. We investigated the quantity of walls that can secure safety against these seismic waves comparing with the models designed by using conventional plywood shear walls. As a result of a number of analytical studies, it was shown that the models using built-in friction mechanism shear walls can suppress the responses to severe earthquake ground motions significantly as well as reduce quantity of walls. 